\title{
PRODUCTION AND CARACTERIZATION OF MONOCLONAL ANTIBODIES FOR THE DETECTION OF SALMONELLA ENTERICA IN CHICKEN MEAT
}

\author{
Andréa dos Santos Schneid; Charli Beatriz Lüdtke; Cristiane Diel; José AntonioGuimarães Aleixo* \\ Centro de Biotecnologia, Universidade Federal de Pelotas, Pelotas, RS, Brasil.
}

Submitted: October 13, 2004; Returned to authors for corrections: February 10, 2005; Approved: June 02 , 2005

\begin{abstract}
A panel of 13 monoclonal antibodies (MAbs) that react against outer membrane proteins of Salmonella Enteritidis was obtained. Two MAbs were classified as $\operatorname{IgM}$, six were $\operatorname{IgG} 2 \mathrm{a}$, three were $\operatorname{IgG} 3$ and one was of the IgG2b isotype. The reactivity of the MAbs against different serovars of Salmonella enterica and other bacteria was investigated using an indirect ELISA. Five MAbs reacted only against Salmonella Enteritidis. Two MAbs presented crossed reactions with thermo-extracted antigens of Klebsiella pneumoniae, Citrobacter freundii and Enterobacter aerogenes. MAb 424H presented wide spectrum of reactivity, detecting antigens of Salmonella belonging to serogroups B, C, D, E and G. The detection limit of different serovars of Salmonella in a indirect ELISA with MAb 424H varied from $1.0 \times 10^{4} \mathrm{CFU} / \mathrm{mL}$ for Salmonella London to $1.4 \times 10^{6} \mathrm{CFU} / \mathrm{mL}$ for Salmonella Gallinarum and Salmonella Typhimurium. Evaluation of the performance of the ELISA with MAb $424 \mathrm{H}$ in the detection of Salmonella in samples of chicken meat artificially contaminated revealed that the ELISA was able to detect all serovars after sample enrichment using two levels of contamination. Samples of chicken meat not artificially contaminated analysed in parallel were negative for Salmonella in both the conventional and the ELISA methods.
\end{abstract}

Key words: Salmonella, monoclonal antibodies, membrane proteins, foods

\section{INTRODUCTION}

Salmonella is an enterobacteria that causes one of the most dangerous foodborne infections and its presence in food represents a serious risk for public health. In Brazil, its occurrence has been observed in several types of food items, mainly of animal origin $(10,21,22)$. In function of the risks that the Salmonella represents for the consumers, its detection in foods is of basic importance. The food producers, as well as the competent agencies of control, have been alert for the necessity to certify the absence of Salmonella in foods (3). Conventional methodology for identifying Salmonella is based on isolation in pure cultures, biochemical and serological tests. This methodology requires a substantial amount of time to be carried out and is expensive (8). For this reason, different systems for the rapid detection of Salmonella antigens in food samples have been proposed, such as the enzyme-linked immunosorbent assay (ELISA) (20,31). ELISA-type tests use polyclonal or monoclonal antibodies or a combination of both. However, the use of polyclonal antibodies in these tests may produce a high number of false positive results due to cross reactions between antibodies present in the polyclonal serum and antigens from other bacteria or even food components (17). Many monoclonal antibodies specific for Salmonella epitopes have been used and provide more reliable ELISA results (7). Many of these tests are commercially available on the Brazilian market in the form of imported kits that are significantly more expensive than in their country of origin. For this reason, the development of novel reagents for diagnostics, has become economically important in Brazil, and among these, are the monoclonal antibodies, used for detection of Salmonella in foods. In this study we report on the production of specific monoclonal

*Corresponding Author. Mailing address: Centro de Biotecnologia, Universidade Federal de Pelotas, Campus Universitário. 96010-900, Pelotas, RS, Brasil. Fax: (+5553) 275-7350. E-mail: biotjaga@ufpel.tche.br 
antibodies against Salmonella Enteritidis outer membrane proteins and on the evaluation of the potential of one of the MAbs for use in a indirect ELISA for the detection of Salmonella enterica in chicken meat.

\section{MATERIALS AND METHODS}

\section{Bacteria}

The origin and identification of Salmonella strains and other Gram negative bacteria used in this study are shown in Table 1. The bacteria were cultivated in brain heart infusion broth (BHI; Difco Laboratories, Detroit, MI) for 24 hours at $37^{\circ} \mathrm{C}$, streaked an nutrient agar (Difco) and subjected to Gram staining for checking purity. Pure cultures of all strains were stored at $-20^{\circ} \mathrm{C}$ in $\mathrm{BHI}$ broth containing $15 \%$ glycerol.

\section{Antigens}

\section{Heat-extracted antigens}

Salmonella and other gram-negative bacteria cultivated in $\mathrm{BHI}$ broth for 24 hours at $37^{\circ} \mathrm{C}$, or samples of artificially contaminated chicken meat after postenrichment in $\mathrm{BHI}$ for 6 hours at $37^{\circ} \mathrm{C}$, were heated to $100^{\circ} \mathrm{C}$ for 10 minutes. The pure cultures of Salmonella and other bacteria had their $\mathrm{OD}_{600}$ adjusted for 1.0 before being heat treated. The heat-extracted antigens were stored at $-20^{\circ} \mathrm{C}$ until use.

\section{Protein antigens from the external membrane}

Proteins from the outer membrane (OMP) of Salmonella Enteritidis ATCC 13076 were isolated using the methodology of Filip et al. (9). Salmonella Enteritidis was cultivated in $1.5 \mathrm{~L}$ of BHI broth at $37^{\circ} \mathrm{C}$ in an orbital shaker at $150 \mathrm{rpm}$ for 24 hours. The culture was centrifuged at $15,000 \mathrm{~g}$ for 15 minutes, washed three times in $0.85 \%$ saline solution and finally resuspended in $10 \mathrm{~mL}$ Tris-HCI $(10 \mathrm{mM})$-EDTA $(5 \mathrm{mM})$ buffer, $\mathrm{pH} 7.8$ (Tris). The cells were sonicated five times with one minute pulses at 20 kcycles per second, with cooling intervals in ice for one minute, and then centrifuged at $15,000 \mathrm{~g}$ for 30 minutes in order to remove cellular debris. The supernatant was mixed with $2.5 \mathrm{~mL}$ of n-laurilsarcosine (Sigma Chemical CO., St. Louis, MO) 2\% (p/v) in Tris buffer and kept for 30 minutes at room temperature. After ultra-centrifugation at 300,000g for one hour the sample was resuspended in $5 \mathrm{~mL}$ Tris buffer and mixed with one volume of detergent solution. After one hour at room temperature the mixture was again ultra-centrifuged and the precipitate washed in $0.85 \%$ saline solution and resuspended in $5 \mathrm{~mL}$ Tris buffer. The material
Table 1. Bacterial strains used in this study.

\begin{tabular}{|c|c|c|c|}
\hline Bacteria & Identification & Origen & Serovar \\
\hline Salmonella Typhimurium & aATCC 14028 & ${ }^{c}$ FIOCRUZ & B \\
\hline Salmonella Typhimurium & ATCC 13311 & FIOCRUZ & $\mathrm{B}$ \\
\hline Salmonella Typhimurium & - & ${ }^{\mathrm{d}} \mathrm{LARA} / \mathrm{RS}$ & $\mathrm{B}$ \\
\hline Salmonella Typhimurium & - & LARA/RS & $\mathrm{B}$ \\
\hline Salmonella Typhimurium & - & ${ }^{\mathrm{e}}$ Cenbiot.Pel & $\mathrm{B}$ \\
\hline Salmonella Agona & - & LARA/RS & $\mathrm{B}$ \\
\hline Salmonella Heidelberg & - & LARA/RS & $\mathrm{B}$ \\
\hline Salmonella Choleraesuis & ATCC 10708 & FIOCRUZ & $\mathrm{C}$ \\
\hline Salmonella Choleraesuis & - & LARA/RS & $\mathrm{C}$ \\
\hline Salmonella Hadar & - & LARA/RS & $\mathrm{C}$ \\
\hline Salmonella Albany & - & LARA/RS & $\mathrm{C}$ \\
\hline Salmonella Infantis & - & LARA/RS & $\mathrm{C}$ \\
\hline Salmonella Infantis & - & Cenbiot.Pel & $\mathrm{C}$ \\
\hline Salmonella Emek & - & LARA/RS & $\mathrm{C}$ \\
\hline Salmonella Enteritidis & ATCC 13076 & FIOCRUZ & $\mathrm{D}$ \\
\hline Salmonella Enteritidis & - & LARA/RS & $\mathrm{D}$ \\
\hline Salmonella Dublin & - & LARA/RS & $\mathrm{D}$ \\
\hline Salmonella Dublin & - & LARA/RS & $\mathrm{D}$ \\
\hline Salmonella Gallinarum & - & LARA/RS & $\mathrm{D}$ \\
\hline Salmonella Anatum & - & LARA/RS & $\mathrm{E}$ \\
\hline Salmonella London & - & LARA/RS & $\mathrm{E}$ \\
\hline Salmonella Typhi & ATCC 10749 & FIOCRUZ & G \\
\hline Salmonella Typhi & ATCC 6539 & FIOCRUZ & G \\
\hline Salmonella Arizona & ATCC 13314 & FIOCRUZ & $\mathrm{G}$ \\
\hline Citrobacter freundii & ATCC 8090 & FIOCRUZ & - \\
\hline Edwardsiella tarda & ATCC 15957 & FIOCRUZ & - \\
\hline Enterobacter aerogenes & ATCC 13048 & FIOCRUZ & - \\
\hline Enterobacter cloacae & ATCC 13047 & FIOCRUZ & - \\
\hline Escherichia coli & ${ }^{\mathrm{b}} \mathrm{CDC} 423-70$ & FIOCRUZ & - \\
\hline Escherichia coli & CDCEDL 1284 & FIOCRUZ & - \\
\hline Klebsiella pneumoniae & ATCC 8329 & FIOCRUZ & - \\
\hline Klebsiella pneumoniae & ATCC 10031 & FIOCRUZ & - \\
\hline Proteus mirabilis & ATCC 15290 & FIOCRUZ & - \\
\hline Proteus vulgaris & ATCC 13315 & FIOCRUZ & - \\
\hline Shigella sonnei & ATCC 25931 & FIOCRUZ & - \\
\hline Edwardsiella tarda & ATCC 15947 & FIOCRUZ & - \\
\hline Serratia marcescens & ATCC 13380 & FIOCRUZ & - \\
\hline Pseudomonas aeruginosa & ATCC 25619 & FIOCRUZ & - \\
\hline Yersinia enterocolitica & - & LARA/RS & - \\
\hline
\end{tabular}

${ }^{\mathrm{a}}$ American Type Culture Collection; ${ }^{\mathrm{b}}$ Center for Disease Control-USA; ${ }^{\mathrm{c}}$ Fundação Oswaldo Cruz - Brazil; ${ }^{d}$ Laboratório Nacional de Referência Animal - Brazil; ${ }^{\mathrm{e}}$ Centro de Biotecnologia - UFPEL - Brazil.

was dialyzed against $0.85 \%$ saline solution and the protein concentration was determined using the Bradford method (2). The efficiency of the OMP extraction process was analyzed by SDS-PAGE electrophoresis (12). 


\section{Monoclonal Antibodies (MAbs)}

The panel of 13 MAbs was obtained according to procedures recommended by Goding (11). BALB/c mice of three to four weeks of age were immunised via intraperitoneal with the OMP from Salmonella Enteritidis. At the end of the immunization protocol the mouse with the highest ELISA titer of anti-OMP antibodies was sacrificed and its spleen was removed for use in the fusion process. The spleen cells were fused to Sp2/0-Ag14 cells with polyethyleneglycol (PEG; Sigma). Selection of hybridomas was carried out using Dulbecco's Modified Eagle's Medium (DMEM; Sigma) with hypoxanthine, aminopterin and thymidine (HAT). After 10 to 14 days, supernatants were screened using an indirect ELISA to detect hybridomas secreting specific antibodies for OMPs of Salmonella Enteritidis. The hybridomas selected were cloned twice by limiting dilution and expanded to be used in production of ascites or for storage in liquid nitrogen. Isotyping of MAbs was carried out with an ELISA test that used specific antibody class/subclass (Calbiochem, Calbiochem-Novabiochem Corporation, San Diego, California).

\section{MAb specificity and immunoblotting}

Heat-extracted antigens of Salmonella and other bacteria listed in Table 1 were used in an indirect ELISA to verify MAb specificity. For immunoblotting the OMP preparations were separated in SDS-PAGE and transferred (12V/15h) to pure nitrocellulose membrane (Bio-Rad Laboratories, Richmond, CA.) (12). The membrane was blocked for 30 minutes with phosphatebuffered saline (PBS) - Tween 20 containing 5\% skimm milk powder and tested with the panel of MAbs. The antigen: antibody complex was detected using an anti-mouse $\mathrm{IgG}$ peroxidase conjugate (DAKO Corporation, USA) and a solution of hydrogen peroxide $\left(\mathrm{H}_{2} \mathrm{O}_{2}\right)$ and 4-chloronaftol as substrate. After 15 minutes the reaction was interrupted with water.

\section{Limit of detection of the indirect ELISA}

The number of cells needed to obtain a positive reaction in the indirect ELISA with MAb $424 \mathrm{H}$ was determined using cultures from different Salmonella strains grown in BHI broth for six hours at $37^{\circ} \mathrm{C}$. After adjusting the $\mathrm{OD}_{600}$ to 1.0 with $\mathrm{BHI}$ the cultures were i) diluted in base 10 in BHI, plated out in nutrient agar and incubated for 24 hours at $37^{\circ} \mathrm{C}$ in order to obtain a total count, or ii) diluted in base 2 in $\mathrm{BHI}$ broth, treated at $100^{\circ} \mathrm{C}$ for 10 minutes and used in an indirect ELISA as described below.

\section{Salmonella detection in artificially contaminated chicken meat}

Samples of salmonella free raw chicken meat were spiked with different serovars of Salmonella. Each serovar was cultivated in $\mathrm{BHI}$ broth for six hours at $37^{\circ} \mathrm{C}$, the cellular suspensions had their $\mathrm{OD}_{600}$ standardized to 1.0 and were used to prepare three $25 \mathrm{~g}$ samples, with different levels of contamination (1-10, 10-10 and $\left.10^{2}-10^{3} \mathrm{CFU}\right)$. Decimal dilutions from each standardized suspension were also prepared in order to carry out a viable cell count. After contamination the samples were screened for Salmonella using the conventional method recommended in the Bacteriological Analytical Manual - Food and Drug Administration (8) and an indirect ELISA with MAb 424H which was selected due to its greater specifity among the panel of $13 \mathrm{MAbs}$. For the indirect ELISA, $0.5 \mathrm{~mL}$ of each selective enrichment broth used in the conventional detection methodology were inoculated in a tube containing $10 \mathrm{~mL}$ of BHI broth and a post-enrichment step was carried out in a water bath shaker for six hours at $37^{\circ} \mathrm{C}$. The post-enrichment cultures were heated $\left(100^{\circ} \mathrm{C} / 10\right.$ minutes $)$ and used to coat polystyrene ELISA plates (Nunc, Brand Products, Dinamarca) with $50 \mu \mathrm{L}$ per well for one hour at $37^{\circ} \mathrm{C}$. Four wells were used for each culture, two to react with MAb $424 \mathrm{H}$ and two without MAb for control of non specific reactions. After coating, the plates were washed three times with PBS $0.01 \mathrm{M}, \mathrm{pH} 7.2$, containing $0.05 \%$ Tween 20 (PBST). $50 \mathrm{~mL}$ of MAb diluted 1:1000 in PBST was added to each well and left for one hour at $37^{\circ} \mathrm{C}$. The plates were then rewashed three times with PBST and $50 \mu \mathrm{L}$ of protein A-peroxidase conjugate (Sigma, Saint Louis, MO) diluted 1:2000 in PBST was added and left for one hour at $37^{\circ} \mathrm{C}$. After washing five times, 50 $\mu \mathrm{L}$ of chromogen/substract (40 mg of ortophenylenediamine dihydrochloride, $40 \mu \mathrm{L}$ of $\mathrm{H}_{2} \mathrm{O}_{2}$ and $100 \mathrm{~mL}$ of phosphate-citrate buffer $0.05 \mathrm{M}, \mathrm{pH} 4.5$ ) was added to each well and left to react for 15 minutes in the dark, at room temperature. The optic density (OD) was then measured at $450 \mathrm{~nm}$ in a MR 700 microplate reader (Dynatech Laboratories, INC., Virginia). As a positive control, each plate had four wells coated with antigen that was heatextracted from Salmonella Enteritidis ATCC 13076. As a negative control, four wells were coated with a mixture of antigens that were heat-extracted from negative sample cultures using the conventional method. The ELISA was considered to be acceptable when the $\mathrm{OD}_{450}$ of the positive control was between 1.0 and 1.2 and the negative control was the same or less than 0.095. The ELISA cut off point, defined as the value of $\mathrm{OD}_{450}$ corresponding to $96 \%$ of 20 negative samples, was 0.095 .

In order to investigate the possibility of reducing ELISA analysis time, tests were also carried out with samples nonselectively enriched for six hours.

\section{RESULTS}

\section{OMP antigens}

The efficiency of protein extraction from the external membrane of Salmonella Enteritidis was verified using SDSPAGE. Several peptide bands could be seen after staining with coomassie blue (Sigma), among which there was a strong band with a molecular mass of approximately $36 \mathrm{kDa}$ (Fig. 1). This preparation was used in the immunization protocol and in the ndirect ELISA during the selection of hybridomas. 


\section{Characterization of monoclonal antibodies}

Isotyping results classified two MAbs as IgM (313D and $3210 \mathrm{~A}$ ) and the others as $\mathrm{IgG}$. Among the IgGs, six were of the subclass IgG2a (MAbs 118F, 416C, 416H, 4212B, 4112C and 425D), four of the subclass IgG3 (MAbs 223C, 336D, 348C and $424 \mathrm{H}$ ) and one of the subclass IgG2b (MAb 495B). The reactivity of MAbs with different strains of Salmonella and with other bacteria was investigated using an indirect ELISA as shown in Table 2. Five MAbs reacted only with Salmonella Enteritidis. Two MAbs showed a cross reactions with heatextracted antigens from Klebsiella pneumoniae, Citrobacter freundii and Enterobacter aerogenes. The MAb 424H showed a wider range of reactivity, detecting antigens of Salmonella belonging to serogroups B, C, D, E and G. A immunoblotting using a preparation of OMP from Salmonella Enteritidis revealed that this antibody reacts with a band of $36 \mathrm{kDa}$ (Fig. 1).

\section{Limit of detection of the ELISA}

The limit of detection for different strains of Salmonella in ELISA with MAb $424 \mathrm{H}$ was determined. In order to obtain a positive reaction it was necessary to have a minimum of $1.0 \times 10^{4}$ $\mathrm{CFU} / \mathrm{mL}$ for Salmonella London to a maximum of $1.4 \times 10^{6} \mathrm{CFU} /$ $\mathrm{mL}$ for Salmonella Gallinarum and Salmonella Typhimurium. For the remaining Salmonella serovars tested the limit of detection was $10^{5} \mathrm{CFU} / \mathrm{mL}$. These concentrations of bacteria in the culture media represents $10^{2}$ to $10^{4}$ per well in the ELISA plates.

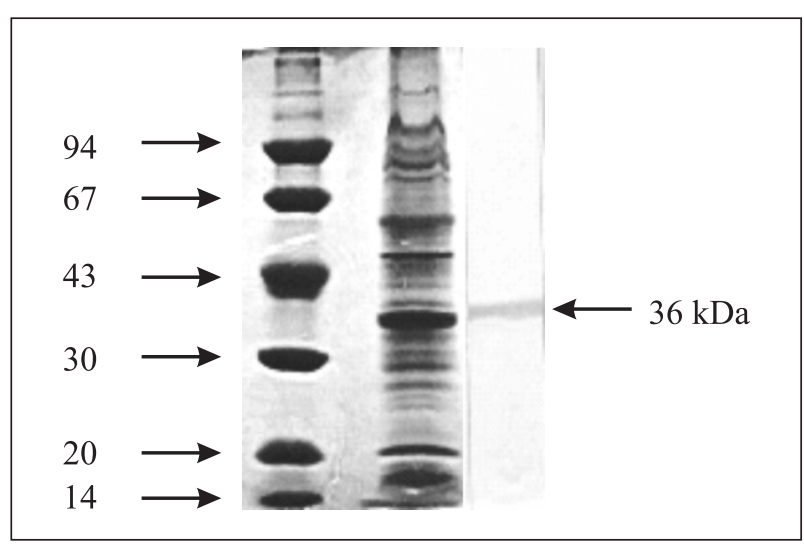

Figure 1. SDS-PAGE and immunoblotting of a Salmonella Enteritidis OMP preparation with MAb 424H. Lane 1, molecular weight marker (Low-range-Sigma); Lane 2, fractions of OMP obtained in the extraction process; Lane 3, OMP of Salmonella Enteritidis blotted with MAb 424H.

\section{Detection of Salmonella in artificially contaminated chicken meat}

The ELISA using MAb 424H was able to detect the presence of all strains after two periods of sample pre-enrichment and the three levels of contamination used (Fig. 2). The analysis of

Table 2. Specificity of MAbs in indirect ELISA using thermo extracted antigens from salmonellae and other bacteria.

\begin{tabular}{|c|c|c|c|c|c|c|c|c|c|c|c|c|c|c|}
\hline \multirow{2}{*}{$\begin{array}{l}\text { Salmonella } \\
\text { (serogroup) }\end{array}$} & \multirow{2}{*}{$\begin{array}{c}\mathrm{N}^{\circ} \text { of strains } \\
\text { tested }\end{array}$} & \multicolumn{13}{|c|}{ MAbs } \\
\hline & & $118 \mathrm{~F}$ & $223 \mathrm{C}$ & $313 \mathrm{D}$ & $3210 \mathrm{~A}$ & $336 \mathrm{D}$ & $348 \mathrm{C}$ & $416 \mathrm{C}$ & $416 \mathrm{H}$ & $424 \mathrm{H}$ & $4212 B$ & $4112 \mathrm{C}$ & $425 \mathrm{D}$ & $415 B$ \\
\hline Agona (B) & 01 & - & - & - & - & - & - & - & - & + & - & - & - & - \\
\hline Heidelberg (B) & 01 & - & + & - & - & - & - & - & - & + & - & - & - & - \\
\hline Choleraesuis $\left(\mathrm{C}_{1}\right)$ & 02 & - & - & - & - & - & - & + & - & + & - & - & - & - \\
\hline $\operatorname{Hadar}\left(\mathrm{C}_{2}\right)$ & 01 & - & - & - & - & - & - & - & - & + & - & - & - & - \\
\hline Albany $\left(\mathrm{C}_{2}\right)$ & 01 & - & - & - & - & - & - & - & - & - & - & - & - & - \\
\hline Infantis $\left(C_{1}\right)$ & 02 & - & - & - & - & - & - & + & - & + & - & - & - & - \\
\hline $\operatorname{EmeK}\left(\mathrm{C}_{2}\right)$ & 01 & - & - & - & - & - & - & + & - & + & - & - & - & - \\
\hline Enteritidis $\left(\mathrm{D}_{1}\right)$ & 02 & + & + & + & + & + & + & + & + & + & + & + & + & + \\
\hline Dublin $\left(\mathrm{D}_{1}\right)$ & 02 & - & - & + & - & - & - & + & + & + & - & - & - & - \\
\hline Anatum $\left(\mathrm{E}_{1}\right)$ & 01 & - & - & - & - & - & - & - & - & - & - & - & - & - \\
\hline London $\left(\mathrm{E}_{1}\right)$ & 02 & - & - & - & - & - & - & - & - & + & + & - & - & - \\
\hline Gallinarum $\left(\mathrm{D}_{1}\right)$ & 02 & - & - & + & + & - & - & + & - & + & + & - & - & - \\
\hline Typhi $\left(\mathrm{G}_{1}\right)$ & 02 & - & - & - & - & - & - & - & - & + & + & - & - & - \\
\hline Arizona $\left(\mathrm{G}_{1}\right)$ & 01 & + & + & - & - & - & - & - & - & - & - & - & - & - \\
\hline Other bacteria & 15 & - & $2^{\mathrm{a}}$ & - & - & - & - & $1^{\mathrm{b}}$ & - & - & - & - & - & - \\
\hline
\end{tabular}

Positive results had $\mathrm{DO}_{450} \geq 0,095 ;$ ( +) reaction with all strains tested; ( - ) absence of reaction; ${ }^{\mathrm{a}}$ reaction with Enterobacter aerogenes $\mathrm{e}$ Proteus mirabilis; ${ }^{\mathrm{b}}$ reaction with com Klebsiella pneumoniae. 


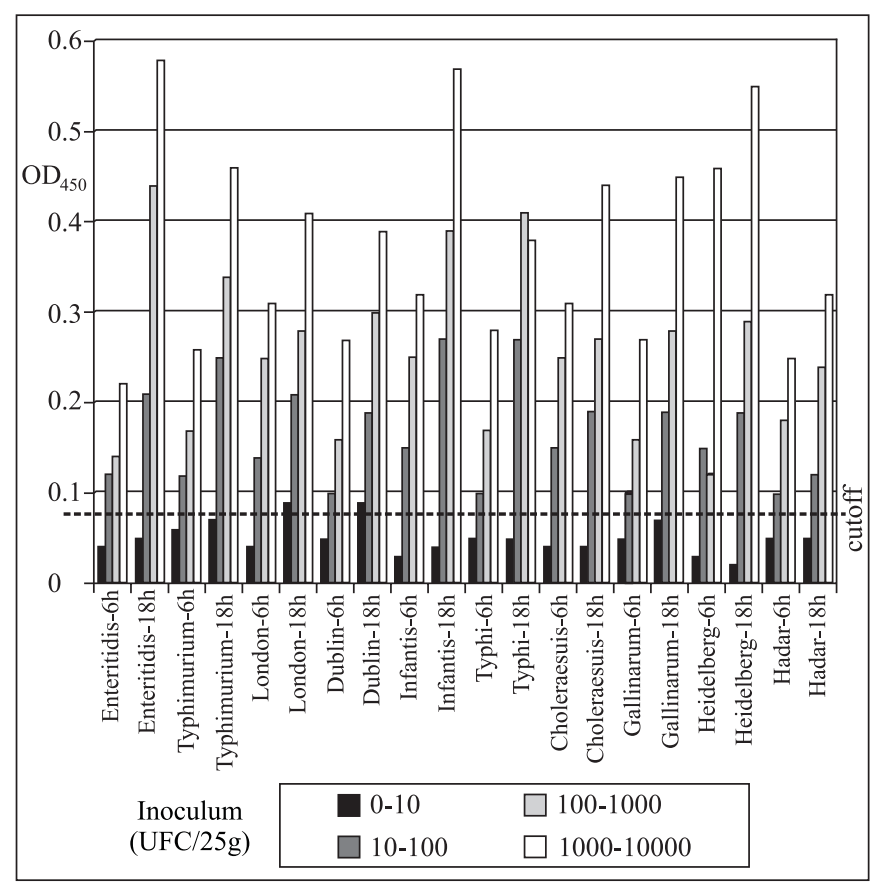

Figure 2. Results of ELISA $\left(\mathrm{OD}_{450}\right)$ performed after different pre-enrichment times of chicken meat artificially contaminated with Salmonella Enteritidis.

aliquots from the samples of chicken that were not artificially contaminated, carried out in parallel, was negative for Salmonella using both ELISA and conventional methods.

\section{DISCUSSION}

Monoclonal antibodies (MAbs) against the outer membrane proteins (OMP) of Salmonella were obtained.The immunogenic potential of these proteins as well as their use in the production of MAbs specific for Salmonella have been evaluated previously $(16,23)$.

Many studies have shown the production of monoclonal antibodies against to structural antigens of Salmonella, such as lipopolysaccharide, flagella and capsula. The use of these MAbs in ELISA tests have improved the detection of Salmonella in foods $(16,19,23,28,29)$. However, sometimes detection may be limited to certain strains due to the antigenic diversity of these bacteria. An example of this is the use of MAbs against flagellar antigens which are only able to identify mobile Salmonella (25). Another exemple is the cross reactivity of MAbs against somatic antigens of Salmonella with antigens of other bacteria due to the homology between these antigens $(13,14,29)$.

For this reason, in the production of MAbs one must select specific antigens that are common to the majority of Salmonella serovars. The OMP used in this study resulted in a panel of
MAbs reacting specifically with Salmonella from several serogroups.

Five MAbs reacted only with Salmonella Enteritidis thereby proving their potential for use in detection tests specific for this strain which is frequently associated with foodborne infections (15). Two MAbs showed cross reactions with antigens of Klebsiella pneumoniae, Citrobacter freundii and Enterobacter aerogenes, which may be related to the antigenic similarity between these bacteria and Salmonella, as has been seen in other studies $(6,16)$. MAb $424 \mathrm{H}$ was highly specific for Salmonella, not reacting with heat-extracted antigens from other bacteria. Moreover, as can be seen in Table 4, this MAb showed a broad range of reactivity, being able to identify strains of Salmonella belonging to serogroups B, C, D, E and G, which are responsible for approximately $95 \%$ of human cases of salmonellosis (27). The immunoblotting showed that MAb $424 \mathrm{H}$ specifically reacted with a polypeptide of approximately $36 \mathrm{kDa}$, a strongly immunogenic fraction of the OMP which represents a highly conserved epitope in different Salmonella serovars. This can be verified by the fact that MAb $424 \mathrm{H}$ has been able to react with heat-extracted antigens from all tested Salmonella strains.

Differences were observed on the detection limits of individual Salmonella serovars, using the indirect ELISA with the MAb 424H. These limits varied from a minimum of $1.0 \times 10^{4}$ $\mathrm{CFU} / \mathrm{mL}$ for Salmonella London to a maximum of $1.4 \times 10^{6} \mathrm{CFU} /$ $\mathrm{mL}$ for Salmonella Typhimurium and Salmonella Gallinarum, and were similar to other published ELISA $(4,5,18,30)$. The variation observed in detection limit may be due to the variable amount of antigen present on the surface of the tested Salmonella serovars. This variation could also be due to differences in the antigen associated to post-polymerization modifications such as glycosylation and acetylation which makes highly specific MAbs unable to react (19).

In the experiment that evaluated the indirect ELISA with $\mathrm{MAb} 424 \mathrm{H}$ in the detection of Salmonella in samples of artificially contaminated chicken, it was shown that the assay was able to detect all strains after the two rounds of enrichment and at the three levels of contamination used. This result shows that, even in presence of the microbial competitors from the chicken meat, Salmonella cells reached levels that were detectable by the ELISA. Different result was found by Wyatt et al. (30) that showed that other microrganism in the sample interfered in the multiplication of Salmonella and reduced ELISA sensitivity. It should be noted that the contamination in the present study was artificial and that Salmonella cells did not suffer any injury which, in turn, favoured its growth even in the presence of competitive flora.

Several protocols of enrichment have been used for the isolation of Salmonella from foods. These protocols serve to inhibit microbial competitors while favours Salmonella growth $(24,26)$. However, it has been shown that many of these protocols can affect negatively the sensitivity of the ELISA, increasing 
the number of false negatives (1). In this study we were able to show that the use of an enrichment protocol with a reduced incubation time does not affect the sensitivity of the ELISA with MAb 424H. Moreover, the ELISA was able to detect Salmonella from a very low level of contamination which allowed us to conclude that MAb $424 \mathrm{H}$ is highly sensitive, being able to detect Salmonella while using an enrichment protocol which reduces pre-enrichment time of the sample by six hours. It should be noticed that the post-enrichment stage used was necessary for the Salmonella cells to reach a minimum detection level in the ELISA with MAb 424H.

In conclusion, 13 MAbs specific for proteins of the external membrane of Salmonella Enteritidis were obtained and characterised. MAb $424 \mathrm{H}$, due to its selectivity and spectrum of reactivity with various strains of Salmonella, was selected for use in an indirect ELISA constructed to detect salmonellae in artificially infected chicken meat and the results suggested a great potential for use in rapid immunochemical methods.

\section{RESUMO}

\section{Produção e caracterização de anticorpos monoclonais para a detecção de Salmonella enterica em carne de frango}

Foi obtido um painel de 13 anticorpos monoclonais que reagem com proteínas de membrana externa de Salmonella Enteritidis. Dois MAbs foram classificados como IgM, 6 foram do isotipo $\operatorname{IgG} 2 \mathrm{a}$, três foram do isotipo IgG3 e um do isotipo $\mathrm{IgG} 2 \mathrm{~b}$. A reatividade dos anticorpos monoclonais (MAbs) com diferentes sorovares de Salmonella e outras bactérias foi investigada através de um ELISA indireto. Cinco MAbs reagiram apenas com Salmonella Enteritidis. Dois MAbs apresentaram reação cruzada com antígenos termoextraídos de Klebsiella pneumoniae, Citrobacter freundii e Enterobacter aerogenes. $\mathrm{O}$ MAb $424 \mathrm{H}$ apresentou amplo espectro de reatividade, detectando antígenos de Salmonella pertencentes aos sorogrupos B, C, D, E, e G. O limite de detecção de diferentes sorovares de Salmonella em um ELISA indireto com o MAb $424 \mathrm{H}$ variou de $1,0 \times 10^{4} \mathrm{UFC} / \mathrm{mL}$ para Salmonella London a 1,4 x $10^{6} \mathrm{UFC} / \mathrm{mL}$ para Salmonella Gallinarum e Salmonella Typhimurium. A avaliação do desempenho do ELISA indireto com o MAb 424H na detecção de diferentes sorovares de Salmonella em amostras de carne de frango, mostrou ser possível detectar todos os sorovares após o enriquecimento das amostras, nos três níveis de contaminação utilizados. A análise de alíquotas de amostras de carne de frango não contaminadas artificialmente, feita em paralelo, foi negativa para Salmonella tanto no método convencional quanto no ELISA.

Palavras-chave: Salmonella, anticorpos monoclonais, proteinas de membrana, alimentos

\section{REFERENCES}

1. Allen, G.; Bruce, V.R.; Stephenson, P. Recovery of Salmonella from high-moisture foods by abreviated selective enrichment. J. Food Protect., 54, 492-495, 1991.

2. Bradford, M.A. A rapid and sensitive method for the quantitation of microgram quantities of protein utilizing the principle of proteindye binding. Anal. Biochem., 72, 248- 254, 1976.

3. Brasil. Ministério da Agricultura e Abastecimento/ Secretaria de Defesa Agropecuária. Método Analítico de Carcaças de Aves e Pesquisa de Salmonella. Diário Oficial da União. Brasília. Portaria SDS no 08 de 23 de janeiro de 1995. p.11182-11188 de 27 de janeiro de 1995. Seção I.

4. Burton, W.B.; Kroll, R.G.; Steell, W. Use of inexpensive O antisera as the detecting antibodies for Salmonella antigens in the polymyxincloth enzyme immunoassay. Int. J. Food Microbiol., 20, 149-158, 1993.

5. Che, Y.H.; Li, Y.; Slavik, M.; Paul, D. Rapid detection of Salmonella Typhimurium in chicken carcass wash water using an immunoelectrochemical method. J. Food Protect., 63 (8), 10431048, 2000.

6. Cheesbrough, S.; Donnelly, C. The use of a rapid Salmonella latex serogrouping test (Spectate) to assist in the confirmation of ELISAbased rapid Salmonella screenig tests. Lett. Appl. Microbiol., 22(5), 378-380, 1996

7. Choi, D.; Tsang, R.S.W.; Ng, M.H. Sandwich capture ELISA by a murine monoclonal antibody against a genus-specific LPS epitope fo the detection of different common serotypes of salmonelas. $J$. Appl. Bacteriol., 72, 134-138, 1992.

8. Food and Drug Administration (FDA) Bacteriological Analytical Manual. 8 ed. Arlington: Association of Official Analytical Chemists, 1998.

9. Filip, C.; Fletcher, G.; Wulff, J.L.; Earhart, C.F. Solubilisation of the cytoplasmic membrane of Escherichia coli by the ionic detergent sodium-lauryl sarcosinate. J. Bacteriol., 115, 717-722, 1973.

10. Fuzihara, T.O.; Franco, B.D.G.M. Bactérias patogênicas e bactérias indicadoras de higiene em carne suína comercializada em Santo AndréSP. Ciênc. Tecnol. Aliment., 13(1), 77-88, 1993.

11. Goding, J.W. Monoclonal antibodies: Principles and practice. New York: Academic Press, 1986, 315p.

12. Harlow, E.; Lane, D. Immunoassay. In: Antibodies: A Laboratory manual. New York: Cold Spring Harbor Laboratory, 1988, 726p.

13. Ibrahim, G.F.; Lyons, M.J.; Walker, R.A. Rapid detection of Salmonellae by immunoassays with titanous hydroxide as the solid phase. Appl. Environment. Microbiol., 50, 670-675, 1985.

14. Keith, M. Evaluation of an automated enzyme-linked fluorescent immunoassay system for the detection of Salmonellae in foods. $J$. Food Protect., 60(6), 682-685, 1997.

15. Keller, L.H.; Benson, C.E.; Garcia, V.; Nocks, E.; Battenfelder, P.; Eckroade, R.J. Monoclonal antibody-based detection system for Salmonella Enteritidis. Avian Dis., 37, 501-507, 1993.

16. Kerr, S.; Ball, H.J.; Mackie, D.P.; Pollock, D.A.; Finlay, D.A. Diagnostic application of monoclonal antibodies to outer membrane protein for rapid detection of salmonella. J. Appl. Bacteriol., 72, 302-308, 1992.

17. Krysinski, E.P.; Heimsch, R.C. Use of a enzyme-labeled antibodies to detect Salmonella in foods. Appl. Environment. Microbiol., 33 (4), 947-954, 1977.

18. Miyamoto, T.; Tian, H.; Matsuno, K. Aplication of monoclonal antibodies to dulcitol 1-phosphate dehydrogenase for rapid detection of Salmonella. J. Food Protect., 58, 847-852, 1995.

19. Ng, S.P.; Tsang, R.S.W.; Luk, J.M.C.; Ng, M.H.; Im, W.K. Two murine monoclonal antibodies against serogroup E Salmonellae. Appl. Environment. Microbiol., 66(1), 419-421, 2000.

20. Peplow, M.O.; Prisant, M.C.; Stebbins, M.E.; Jones, F.; Davies, P. Sensitivity, Specificity, and Predictive Values of Three Salmonella 
Rapid Detection Kits Using Fresh and Forzen Poultry Environmental Samples versus Those of Standart Plating. Appl. Environment. Microbiol., 65(3), 1055-1060, 1999.

21. Ribeiro, A.R.; Nascimento, V.P.; Cardoso, M.O.; Santos, L.R.; Rocha, S.L.S. Utilization of Immunomagnetic separation for detection of Salmonella in raw broiler parts. Bras. J. Microbiol., 33, 339-341, 2002.

22. Santos, D.M.S.; Berchieri Jr, A.; Fernandes, S.A.; Tavechio, A.T.; Amaral, L.A. Salmonella em carcaças de frango congelados. Pesq. Vet. Bras., 20(1), 39-42, 2000.

23. Singh, P.S.; Williams, Y.U.; Benjamin, W.H.; Klebba, P.E.; Boyd, D. Immunoprotection by monoclonal antibodies to the porins and lipopolysaccharide of Salmonella Typhimurium. Microbiol. Phatogenesis., 21, 249-263, 1996.

24. Tate, C.R.; Miller, R.G.; Mallinson, E.T. Evaluation of two isolation and two no-isolation methods for detecting naturally occurring Salmonellae from broiler flock environmental drag-swab samples. J. Food Protect., 55, 964-967, 1992.

25. Timoney, J.F.; Sikora, N.; Shivaprasad, H.L.; Opitz, M. Detection of antibody to Salmonella Enteritidis by a gm flagellin-base ELISA. Vet. Record., 127, 168-169, 1990.

26. Todd, E.C.D.; Mackenzie, J.M.; Peterkin, P.I. Development of an enzyme-linked antibody hydrophobic grid membrane filter method for the detection of Salmonella in foods. Food Microbiol., 10, 87 99, 1993.

27. Torensma, R.; Visser, M.J.C.; Aarsman, C.J.A.; Poppelier, M.J.J.G.; Van Beurden, R.; Fluit, A.C.; Verhoef, J. Monoclonal antibodies that detect live Salmonellae. Appl. Environment. Microbiol., 58(12), 3868-3872, 1992.

28. Tsang, R.S.W.; Chan, K.H.; Chau, P.Y.; Wan, K.C.; Ng, M.H.; Schlecht, S. A murine monoclonal antibody specific for the outer core oligosaccharide of Salmonella lipopolysaccharide. Infect. Immun., 55, 211-216, 1987.

29. Tsang, R.S.W.; Nielsen, K.; Henning, M.D.; Schlecht, S.; Aleksic, S. A murine monoclonal antibody that recognizes a genus-specific epitope in the Salmonella lipopolysaccharide outer core. Int. J. Med. Microbiol., 274, 456-464, 1991.

30. Wyatt, G.M.; Lee, H.A.; Dionysiou, S.; Morgan, M.R.A.; Stokely, D.J.; Al-Hajji, A.H.; Richards, J.; Sillis, A.J.; Jones, P.H. Comparison of a microtitration plate ELISA with a standard cultural procedure for the detection of Salmonella spp. in chicken. J. Food Protect., 59(3), 238-243, 1996.

31. Yoshimasu, M.A.; Zawistowski, J. Application of Rapid Dot Blot Immunoassay for Detection of Salmonella enterica Serovar Enteritidis in Eggs, Poultry, and Others Foods. Appl. Environment. Microbiol., 67(1), 459-461, 2001. 